\title{
PROFIL STRATEGI PEMBELAJARAN BAHASA JEPANG DI SD MUTIARA SINGARAJA
}

\author{
A.Rahmah ${ }^{1}$, D.M.S. Mardani ${ }^{2}$, G.S. Hermawan ${ }^{3}$ \\ 123 Jurusan Pendidikan Bahasa Jepang, Universitas Pendidikan Ganesha, Singaraja,Bali \\ e-mail: aulia.rahmah @undiksha.ac.id \\ desak.mardani@undiksha.ac.id satya.hermawan@undiksha.ac.id
}

\begin{abstract}
Abstrak
Penelitian ini bertujuan untuk mendeskripsikan (1) sasaran pembelajaran bahasa Jepang di SD Mutiara Singaraja, (2) strategi pembelajaran yang digunakan oleh guru untuk mencapai sasaran pembelajaran bahasa Jepang di SD Mutiara Singaraja, (3) faktor-faktor yang mendasari penggunaan strategi dalam pembelajaran bahasa Jepang di SD Mutiara Singaraja, (4) kendala-kendala yang dihadapi dalam kegiatan pembelajaran bahasa Jepang di SD Mutiara Singaraja. Subjek penelitian ini adalah guru bahasa Jepang di SD Mutiara Singaraja. Metode pengumpulan data menggunakan metode observasi, wawancara dan dokumentasi. Teknik analisis data yang digunakan pada penelitian ini adalah analisis deskriptif kualitatif. Hasil penelitian menunjukkan bahwa (1) Sasaran pembelajaran bahasa Jepang di SD Mutiara Singaraja meliputi aspek membaca, aspek menulis, aspek mendengar, aspek berbicara dan pengetahuan budaya; (2) Strategi pembelajaran yang digunakan adalah strategi lagu, strategi tanya jawab, strategi drill, dan strategi ceramah; (3) Faktor-faktor yang mendasari penggunaan strategi pembelajaran bahasa Jepang adalah karakteristik siswa, kemampuan yang dimiliki siswa dan kondisi siswa di kelas; (4) Kendala-kendala yang dihadapi dalam pembelajaran bahasa Jepang adalah karakteristik siswa dan buku ajar.
\end{abstract}

Kata Kunci: pembelajaran, profil, strategi pembelajaran.

\section{要旨}

本研究の目的は、（1）シンガラジャムティアラ私立小学校の日本語学習の目標、（ 2）シンガラジャムティアラ私立小学校の日本語学習の目標を達成するための学習ス トラテジー、（3）シンガラジャムティアラ私立小学校の日本語学習におけるストラ テジー使用の要因、（4）シンガラジャムティアラ私立小学校の日本語学習の障害を 明らかことである。研究の対象は、シンガラジャムティアラ私立小学校の日本語教 師である。調査方法は、観察、インタビュー及び、文献調査である。収集したデー タを定性的記述法により分析した。分析した結果は、（1）日本語学習の目標は、聴く 力・読む力・話す力・書く力・文化の知識という 5 つの能力において、日本語能力 を伸ばすことができることである。（2）日本語学習の目標を達成するための学習ス トラテジーは、歌ストラテジーとQ\&Aストラテジーとドリルと講義である。（3）日 本語学習におけるストラテジ一使用の要因は、生徒の特性と教室の生徒の状態と生 徒の能力である。（4）日本語学習の障害は、生徒の特性と教科書である。 キーワード : 概要、学習、学習ストラテジー 


\section{Pendahuluan}

Hasil survei The Japan Foundation Tahun 2015 menyatakan Indonesia sebagai negara dengan pembelajar bahasa Jepang terbanyak kedua di dunia yakni dengan jumlah 745,125 orang setelah negara Cina. Khususnya provinsi Bali menjadi provinsi terbanyak keempat setelah Jawa Barat, Jawa Timur, dan Jawa Tengah. Jumlah pembelajar bahasa Jepang di Bali yakni 62.845 orang pembelajar yang terbagi menjadi tiga pembelajar yaitu SD 1.817 orang, SMP 5.575 orang, dan SMA 55.453 orang. Pembagian tiga golongan usia pembelajar tentunya dipengaruhi oleh tersedianya sekolah yang mengadakan pembelajaran bahasa Jepang baik pada tingkat SD, SMP, dan SMA (The Japan Foundation Survey: 2015).

SD Mutiara Singaraja merupakan sekolah swasta yang menjadi satu-satunya sekolah dasar yang mengadakan pembelajaran bahasa Jepang di kabupaten Buleleng. Bahasa Jepang di SD Mutiara Singaraja bersifat ekstrakurikuler pilihan yang bebas dipilih siswa. Ekstrakurikuler bahasa Jepang di SD Mutiara Singaraja merupakan kegiatan pembelajaran yang diadakan seminggu sekali dengan durasi waktu dua jam per pertemuan. Kegiatan ekstrakurikuler adalah kegiatan tambahan di luar struktur program yang dilaksanakan di luar jam biasa agar memperkaya dan memperluas wawasan pengetahuan dan kemampuan siswa (Suryosubroto, 2002). Sesuai dengan pendapat tersebut, kegiatan ekstrakurikuler bahasa Jepang di SD Mutiara Singaraja juga merupakan kegiatan pembelajaran yang dilaksanakan di luar jam pelajaran yakni pada siang atau sore hari setelah pelajaran di sekolah berakhir.

Berdasarkan hasil wawancara yang dilakukan pada tanggal 9 Januari 2018 kepada guru pengajar bahasa Jepang dalam kegiatan ekstrakurikuler, tujuan diadakannya kegiatan ekstrakurikuler bahasa Jepang di SD Mutiara Singaraja adalah sebagai sebagai penambah wawasan dan keterampilan siswa terhadap bahasa asing. Selain itu sesuai dengan Kurikulum SD Mutiara Singaraja Tahun Ajaran 2017/2018, tujuan ekstrakurikuler bahasa Jepang merupakan salah satu upaya sekolah dalam pemberian kesempatan kepada siswa untuk mengembangkan dan mengekspresikan diri sesuai dengan kebutuhan dan minat setiap siswa.

Salah satu skarakteristik siswa di SD Mutiara Singaraja adalah tingkat konsentrasi siswa yang rendah dalam mengikuti pembelajaran. Siswa SD memiliki karakteristik senang bergerak sehingga siswa SD dapat duduk dengan tenang selama 30 menit (Sumantri dan Syaodih, 2006). Sehingga dalam proses pembelajaran siswa merasa cepat bosan dan cenderung tidak memperhatikan pembelajaran. Karakteristik siswa ini merupakan salah satu kendala yang dihadapi guru pengajar bahasa Jepang di SD Mutiara Singaraja.

Kendala lainnya dinyatakan oleh guru adalah tidak tersedianya buku ajar yang dapat digunakan sebagai sumber materi dalam pembelajaran bahasa Jepang di SD Mutiara Singaraja. Hal ini terjadi karena bahasa Jepang bukan merupakan pelajaran wajib sehingga dari pihak sekolah belum menyediakan buku penunjang dalam pembelajaran bahasa Jepang. Dalam pembelajaran bahasa Jepang guru secara mandiri menentukan materi pembelajaran dengan berbantuan media internet. Dengan kendala yang terjadi dalam proses pembelajaran bahasa Jepang di SD Mutiara Singaraja guru tetap mengupayakan agar pembelajaran dapat mencapai sasaran yang telah ditentukan.

Sasaran pembelajaran bahasa Jepang sebagai ekstrakurikuler di SD Mutiara Singaraja tidak hanya pada pengetahuan bahasa Jepang tetapi juga pada pengetahuan budaya Jepang itu sendiri. Bahasa asing sekolah dasar merupakan program pengajaran bahasa yang memiliki tujuan utama adalah agar para siswa memperoleh kesadaran budaya dan sejumlah keterampilan menyimak dan berbicara dalam bahasa asing sesuai program (Tarigan, 1984). Sehingga dalam proses pembelajaran bahasa Jepang di SD Mutiara Singaraja, guru tidak hanya mengajarkan materi bahasa Jepang tetapi juga berupa pengetahuan budaya Jepang.

Berdasarkan beberapa karakteristik siswa dan pembelajaran bahasa Jepang di SD Mutiara Singaraja yang telah dipaparkan, penelitian ini dinilai perlu untuk dilakukan agar mengetahui lebih dalam lagi mengenai pembelajaran bahasa Jepang di SD Mutiara Singaraja. Penelitian ini juga dilakukan untuk memaparkan lebih lanjut tentang temuan- 
temuan lain yang kemungkinan muncul dalam pembelajaran bahasa Jepang di SD Mutiara Singaraja.

Selain itu dari hasil survei The Japan Foundation Tahun 2015 yang menyatakan rendahnya pembelajar bahasa Jepang di SD juga memengaruhi belum adanya penelitian profil pembelajaran bahasa Jepang di tingkat SD. Sehingga penelitian ini mampu menjadi sumber referensi bagi pengajar bahasa Jepang dan peneliti lain untuk mengetahui gambaran dan perbedaan pembelajaran bahasa Jepang di tingkat SD. Atas dasar itulah menjadikan penelitian ini dianggap semakin penting untuk dilakukan.

Penelitian terkait profil strategi pembelajaran bahasa Jepang telah banyak dilakukan salah satunya oleh Marsutayasa (2013). Selain itu penelitian terkait strategi pembelajaran bahasa Jepang di tingkat SMA juga telah dilakukan oleh Yastini (2015). Namun Marsutayasa (2013) juga menghubungkan deskripsi strategi pembelajaran bahasa Jepang dengan kurikulum 2013, sedangkan Yastini (2015) memiliki perbedaan dengan mengkhususkan penelitian pada satu jenis keterampilan bahasa yaitu menulis.

Sehingga atas dasar inilah penulis bermaksud untuk melaksanakan penelitian mengenai pembelajaran bahasa Jepang di SD Mutiara Singaraja yang dituangkan dalam judul "Profil Strategi Pembelajaran Bahasa Jepang Di SD Mutiara Singaraja".

Dari latar belakang yang telah dipaparkan, dapat dirumuskan permasalahan adalah sebagai berikut.

1. Apa sasaran pembelajaran bahasa Jepang di SD Mutiara Singaraja?

2. Apa dan bagaimana strategi pembelajaran yang digunakan guru untuk mencapai sasaran dalam pembelajaran bahasa Jepang di SD Mutiara Singaraja?

3. Apa saja faktor-faktor yang mendasari penggunaan strategi dalam pembelajaran bahasa Jepang di SD Mutiara Singaraja?

Apa kendala-kendala yang dihadapi dalam kegiatan pembelajaran bahasa Jepang di SD Mutiara Singaraja?

\section{Metode}

\section{Metode Pengumpulan Data}

Pengumpulan data dilakukan dengan metode observasi, wawancara dan dokumentasi.

Observasi yang dilakukan dalam penelitian ini adalah observasi partisipasi pasif yaitu dengan hanya melakukan pengamatan dan pencatatan langsung tanpa terlibat dalam kegiatan pembelajaran bahasa Jepang yang dilaksanakan di SD Mutiara Singaraja.

Wawancara pada penelitian menggunakan subjek penelitian yaitu guru pengajar bahasa Jepang di SD Mutiara Singaraja. Penelitian ini menggunakan teknik terencana tapi tak berstruktur (wawancara semi terstruktur) yakni pertanyaan wawancara telah disusun sebelumnya, tetapi jika ada jawaban yang dianggap menarik dan perlu adanya pendalaman bagi pewawancara, pewawancara dapat memperdalam pertanyaan tanpa terikat pada pertanyaan yang telah disusun sebelumnya.

Dokumentasi dalam penelitian ini berupa pengumpulan data berupa dokumen yang terkait dengan pembelajaran seperti, bahan ajar atau materi, media pembelajaran,absensi kehadiran siswa, foto kegiatan pembelajaran di kelas, dan lain-lain.

\section{Metode Dan Teknik Analisis Data}

Teknik analisis dalam penelitian ini menggunakan teknik analisis kualitatif. Tahapan analisis data dalam penelitian ini yakni (1) tabulasi data yaitu data yang diperoleh berupa hasil observasi, hasil wawancara, dan dokumetasi digabungkan dan diklasifikasikan, (2) reduksi data yaitumenyederhanakan data hasil observasi pembelajaran bahasa Jepang, (3) deskripsi data yaitu penyajian hasil data yang telah diperoleh dalam bentuk deskripsi atau uraian yang sesuai dengan fakta yang ditemukan di lapangan, (4) klasifikasi data yaitu proses pengelompokkan data yang sesuai ataurelevan berdasarkan tujuan penelitian, (5) penarikan kesimpulan yaitu penentuan jawaban dari permasalahan yang telah dirumuskan.

\section{Hasil dan Pembahasan}




\section{Sasaran Pembelajaran}

Sasaran pembelajaran bahasa Jepang sebagai ekstrakurikuler di SD Mutiara Singaraja yaitu yang pertama pada aspek berbicara meliputi kemampuan siswa dalam melafalkan bunyi, kata, dan ungkapan dalam bahasa Jepang. Hal ini dapat dilihat dari penggunanaan aisatsu (sapaan) setiap mengawali pembelajaran dalam bahasa Jepang yang memuculkan respon siswa. Selain itu upaya peningkatan kemampuan berbicara juga terlihat dari penggunaan strategi tanya jawab dan drill untuk melatih kemampuan siswa dalam pengucapan bahasa Jepang.

Kedua yaitu pada aspek mendengar yang berkaitan dengan kemampuan siswa dalam menangkap kosakata dalam bahasa Jepang dan membedakan cara pelafalan kosakata dalam bahasa Jepang. Dalam kegiatan menangkap kosakata bahasa Jepang, guru mengadakan kegiatan pembacaan hasil latihan yang telah dibuat oleh siswa. Siswa yang lain diinstruksikan untuk memperhatikan teman yang sedang membacakan hasil pekerjaannya di depan kelas. Setelah pembacaan hasil latihan siswa selesai, guru mengetes pendengaran siswa dengan cara mengajukan pertanyaan. Selain itu upaya peningkatan kemampuan mendengarkan juga dilakukan ketika pengenalan kosakata dalam bahasa Jepang berlangsung. Guru mengulang pengucapan kosakata bahasa Jepang dengan keras dan benar sehingga siswa dapat terbiasa dalam mendengarkan kosakata dalam bahasa Jepang.

Ketiga pada aspek menulis yaitu siswa mampu menulis kosakata maupun kalimat dengan menggunakan huruf Jepang baik huruf kana maupun Romaji. Kemampuan menulis dilatih dengan mewajibkan seluruh siswa untuk memiliki buku bergaris kotak pada setiap pertemuan dalam materi "Huruf". Siswa diberikan latihan untuk menulis huruf dengan jumlah tertentu. Selain itu siswa juga dilatih dalam penulisan contoh kosakata dengan menggunakan huruf Hiragana maupun Katakana. Untuk kemampuan menulis dalam setiap pembelajaran bahasa Jepang, guru juga menekankan pada kemampuan siswa dalam menulis kosakata bahasa Jepang dengan menggunakan huruf Romaji (Alfabet). Hal ini terlihat pada setiap kegiatan komunikasi tulisan yang dilakukan oleh guru hanya dengan menggunakan huruf Romaji.

Keempat pada aspek membaca yakni siswa mampu membaca kosakata maupun kalimat dalam huruf HiraganadanKatakanamaupun huruf Romaji (Alfabet). Siswa dilatih untuk membaca berbagai kosakata bahasa Jepang dengan huruf Hiragana atau Katakana. Sedangkan kemampuan membaca huruf Romaji dilakukan dalam setiap pertemuan pembelajaran. Hal ini terlihat dari kegiatan guru setelah selesai menulis materi di papan tulis, guru selalu mengintruksikan siswa untuk membaca secara bersama-sama kosakata bahasa Jepang yang ditulis dengan huruf Romaji. Dalam kegiatan membaca huruf Romaji (Alfabet), guru juga menjelaskan ada perbedaan cara membaca huruf alfabet dalam Jepang yang berbeda dengan huruf alfabet dalam bahasa Indonesia. Seperti huruf $n$ dapat dibaca $\mathrm{n} / \mathrm{m} / \mathrm{ng}$ dan huruf shi dibaca syi.

Kelima adalah siswa diharapkan memperoleh pengetahuan tentang Jepang secara umum baik berupa bahasa, gaya hidup maupun budaya Jepang. Hal ini terlihat dalam setiap pembelajaran materi yang diberikan, guru mengaitkan pembelajaran dengan budaya yang ada di Jepang. Seperti dalam materi "Nama Alat Transportasi", guru menjelaskan bahwa di Jepang memiliki kereta tercepat yang bernama shinkansen. Selain itu, menurut hasil wawancara, guru juga sebelumnya pernah mengajarkan tentang budaya origami yakni melipat kertas. Guru mengajak siswa untuk berlatih membuat origami.

\section{Strategi yang Digunakan dalam Pembelajaran}

Dalam proses pembelajaran bahasa Jepang di SD Mutiara Singaraja guru terlihat memaksimalkan tahapan bahasa Jepang dasar yaitu pertama 導入(dounyuu) atau latihan pengenalan dan kedua基本練習 (kihon renshuu) atau latihan dasar. Sedangkan untuk tahapan応用練習 (ouyou renshuu) atau latihan penggunaan dalam pembelajaran bahasa Jepang di SD Mutiara Singaraja belum terlaksana. 
Tahap導入(dounyuu) atau latihan pengenalan dilakukan dengan kegiatan pengenalan kosakata baru, pola kalimat, dan contoh kalimat dengan menggunakan bahasa Indonesia (bahasa ibu). Pengenalan kosakata menggunakan media tambahan yaitu e kaado (kartu bergambar).

Tahap基本練習 (kihon renshuu) atau latihan dasar dilakukan dengan penggunaan strategi drill terkait kosakata dan pola kalimat yang telah dipelajari. Selain itu guru juga memberikan pengayaan dengan pemberian latihan pembuatan contoh kalimat baru kepada siswa. Pada tahap ini terdapat kegiatan反復練習(hanpukurenshuu) atau latihan pengulangan kosakata baru, hal ini dilakukan oleh guru agar siswa memiliki ingatan yang kuat terhadap kosakata baru.

Tahap応用練習 (ouyou renshuu) atau latihan penggunaan tidak ditekankan oleh guru dalam pembelajaran bahasa Jepang di SD Mutiara karena terkendala alokasi waktu pembelajaran yang singkat.

Menurut hasil observasi yang telah dilakukan sebanyak 5 kali dapat disimpulkan bahwa guru di SD Mutiara Singarajamenggunakan strategi penggunaan lagu, tanya jawab, drill, dan ceramah dalam proses pembelajaran bahasa Jepang .

\section{Lagu}

Strategi penggunaan lagu selalu dilakukan pada tahap sebelum pembelajaran dimulai. Kegiatan bernyanyi dilakukan secara bersama dengan tujuan membangun semangat siswa dalam memulai pembelajaran. Lagu yang dinyanyikan antara lain Minna de Tahoshiku (Semua Bergembira), Siawase Nara Te O Tatakou (terjemaha lagu If You Happy And You Know Clap Your Hands), dan Kira Kira Hikaru (terjemahan lagu Twinkle Twinkle Little Star).Penggunaan lagu setiap pertemuan di awal pembelajaran dimaksudkan untuk membangun semangat belajar dan menciptakan suasana yang menyenangkan sebelum memulai proses pembelajaran bahasa Jepang. Jadi tidak memiliki hubungan terhadap materi yang akan disampaikan kepada siswa. Temuan ini sejalan dengan pendapat Padmadewi (2012) yang menyatakan, dalam pembelajaran bahasa asing, pemberian lagu memiliki dua fungsi yakni lagu yang berfungsi sebagai penghibur dan lagu yang berfungsi sebagai media pembelajaran.

\section{Strategi Tanya Jawab}

Strategi tanya jawab sering dilakukan oleh guru dalam mengulang materi pelajaran (fukushu) materi sebelumnya. Tanya jawab berupa pemberian pertanyaan terkait materi sebelumnya. Selain itu strategi tanya jawab juga dilakukan sebagai upaya membangun rasa ketertarikan siswa terhadap materi yang akan dipelajari. Temuan ini sejalan dengan Dharma (2008) yang menyatakan, strategi tanya jawab biasanya juga dapat digunakan untuk membangkitkan motivasi dan semangat siswa dalam belajar.Kegiatan応答練習(outou renshuu) latihan merespon dan menjawab dilakukan pada tataran contoh kalimat dengan menggunakan pola kalimat tertentu. Berikut adalah contoh interaksi guru dan siswa yang dilakukan dengan menyebutkan contoh kalimat dalam bahasa Indonesia kemudian siswa ditunjuk untuk menjawab dengan menggunakan bahasa Jepang.

Guru : "Kalau ingin memesan 3 kopi, apa bahasa Jepangnya?"

Siswa : "Koohii wo mitsu kudasai"

Selain dilakukan dalam memancing ingatan siswa terhadap topik pelajaran, guru juga menggunakan strategi tanya jawab pada tahap pengulangan materi (fukushu). Berikut adalah contoh interaksi yang dilakukan oleh guru dan siswa.

\section{Drill}

Strategi drill dilakukan dengan dengan kegiatan 反復練習(hanpukurenshuu) latihan pengulangan kosakata baru, hal ini dilakukan oleh guru agar siswa memiliki ingatan yang kuat terhadap kosakata baru dan mengetahui sejauh mana kemampuan siswa dalam mengingat materi yang diberikan. Sejalan dengan hal itu menurut Dimyati dan Mudjiono (2002), dalam Taksonomi Bloom pada tahap pengetahuan yaitu siswa mencapai kemampuan ingatan tentang hal yang telah dipelari dan tersimpan dalam ingatan. 
Kegiatan 反復練習(hanpukurenshuu) merupakan kegiatan yang menekan kan pada kegiatan siswa dalam meniru pengucapan kosakata yang dilakukan oleh guru dan mengingat kosakata yang telah diucapkan. Sehingga pada tahap ini guru menggunakan teknik mimicry memorization. Dalam proses pembelajaran guru juga menerapkan jenis drill yang lain yakni substitution drillatihan melengkapi (Padmadewi, 2012). Latihan mengganti kata dapat dalam sebuah kalimat maupun sebuah percakapan sederhana. Perbedaanya pada kegiatan ini siswa diizinkan untuk membaca percakapan yang disediakan di papan tulis kemudian siswa mengganti bagian yang kosong sesuai dengan pilihan yang siswa namun tetap sesuai dengan pola kalimat yang telah diajarkan. Berikut adalah contoh percakapan pada materi "Nama Ruangan di Sekolah". Guru mengkosongkan bagian nama ruangan (kyoushitsu) dan kata tunjuk (asoko).

Siswa 1 :"Chotto sumimasen"

Siswa 2 :"Hai"

Siswa1:"Kyoushitsu wa dokodesuka?"

Siswa2 :"Kyoushitsudesuka?Asokodesu"(sambil menunjuk).

Siswa 1 :"Arigatou gozaimasu"

\section{Ceramah}

Strategi ceramah digunakan dalam menjelaskan pola kalimat beserta contoh kalimat. Untuk mengurangi tingkat kebosanan siswa dalam mendengarkan penjelasan, guru menvariasikan dengan strategi tanya jawab. Pertanyaan diusahakan menggunakan pertanyaan menarik terkait materi yang dapat mengarahkan kembali fokus siswa. Setelah penjelasan pola kalimat dilakukan dengan menggunakan strategi ceramah, guru memberikan pengayaan berupa latihan pembuatan contoh kalimat.

\section{Faktor-Faktor yang Mendasari Strategi dalam Pembelajaran}

Suhanji (2008) yang menyatakan, strategi yang akan digunakan harus disesuaikan dengan jenis materi, karakteristik peserta didik, serta situasi atau kondisi di mana proses pembelajaran tersebut akan berlangsung. Faktor yang mendasari strategi dalam pembelajaran bahasa Jepang di SD Mutiara yang pertama yakni karakteristik siswa yang memiliki tingkat kebosanan yang tinggi. Sehingga sesuai dengan karakteristik tersebut guru meggunakan berbagai strategi yang dapat menciptakan kondisi kelas yang aktif. Penggunaan strategi lagu akan meningkatkan semangat siswa dalam memulai proses pembelajaran. Penggunaan strategi tanya jawab, drill, ceramah yang dipadukan dengan strategi tanya jawab akan memperbanyak interaksi siswa dan guru.

Kedua adalah kemampuan yang dimiliki oleh siswa masih rendah. Peserta pembelajaran bahasa Jepang di SD Mutiara Singaraja dalam setiap sesi memiliki tingkatan kelas yang berbeda. Sehingga dalam hal ini guru menggunakan berbagai strategi yang sederhana sehingga semua siswa dapat mengikuti tahapan pembelajaran. Selain itu guru juga pemilihan materi yang sederhana namun tetap memiliki kemenarikan untuk dipelajari.

Ketiga yakni kondisi siswa di kelas dengan berbagai pertanyaan baik yang terkait maupun tidak terkait terhadap materi yang diajarkan. Sehingga dalam hal ini guru menggunakan strategi yang dapat menyalurkan keadaan siswa yang banyak mengajukan pertanyaan dengan punggunaan strategi tanya jawab dan drill. Temuan ini sejalan dengan Sumantri dan Syaodih (2006), sejalan dengan kematangan jasmani, kemampuan anak dalam berbicara untuk berkomunikasi makin meningkat dan meluas.

\section{Kendala-Kendala yangDihadapi Guru dalam Pembelajaran}

Kendala adalah suatu masalah atau suatu keadaaan yang menjadi penghambat untuk mencapai tujuan yang ingin dicapai dan harus memiliki solusi tertentu yang sesuai dengan kendala yang dihadapinya (Soewarno, 2016). Adapun kendala yang dialami guru dalam pembelajaran bahasa Jepang di SD Mutiara Singaraja dilihat dari hasil observasi dan wawancara adalah karakteristik siswa yang memiliki konsentrasi rendah dalam mengikuti pembelajaran. Siswa mudah kehilangan konsentrasi apabila temannya melakukan kegiatan selain belajar seperti mengobrol, bercanda, dan lain-lain. Sehingga untuk mengatasi kendala dalam proses pembelajaran bahasa Jepang di SD Mutiara Singaraja guru menggunakan 
media tambahan seperti media e kaado (kartu bergambar) dan penggunaan strategi contohnya memvariasikan strategi ceramah dengan strategi tanya jawab. Menurut Hamalik (2002), dalam hal ini keterampilan guru, kemampuan siswa merupakan masalah hambatan dalam pengajaran. Sehingga hal-hal yang menyangkut kemampuan dan karakteristik siswa digolongkan pada masalah hambatan.

Kendala kedua tidak adanya buku ajar sebgai sumber materi dalam pembelajaran bahasa Jepang di SD Mutiara Singaraja. Keterbatasan faktor instruksional yaitu terbatasnya media pembelajaran, buku pelajaran, dan alat peraga tergolong masalah hambatan yang dapat menjadi kendala dalam proses pembelajaran (Hamalik, 2002). Sehingga untuk mengatasi kendala tidak adanya buku ajar, guru tetap berusaha mencari materi yang cocok bagi siswa melalui internet.

\section{Simpulan dan Saran}

Berdasarkan hasil penelitian dan pembahasan mengenai profil strategi pembelajaran bahasa Jepang di SD Mutiara Singaraja dapat disimpulkan sebagai berikut.

1. Sasaran pembelajaran bahasa Jepang sebagai ekstrakurikuler di SD Mutiara Singaraja yakni (1) aspek berbicara, (2) aspek mendengarkan, (3) aspek menulis, (4) aspek membaca, (5) pengetahuan tentang Jepang secara umum baik berupa bahasa, gaya hidup maupun budaya Jepang.

2. Strategi yang digunakan dalam pembelajaran bahasa Jepang di SD Mutiara Singaraja adalah strategi penggunaan lagu, tanya jawab, drill, ceramah. Strategi penggunaan lagu selalu dilakukan pada tahap sebelum pembelajaran di mulai. Kegiatan bernyanyi dilakukan secara bersama dengan tujuan membangun semangat siswa dalam memulai pembelajaran. Strategi tanya jawab sering dilakukan oleh guru dalam mengulang materi pelajaran (fukushu) materi sebelumnya. Strategi tanya jawab merupakan kegiatan 応答練習(outou renshuu) latihan merespon dan menjawab terkait kosakata baru berupa pemberian pertanyaan terkait materi yang diajarkan. Selain itu strategi tanya jawab juga dilakukan sebagai upaya membangun rasa ketertarikan siswa terhadap materi yang akan dipelajari. Strategi drill dilakukan dengan dengan kegiatan 反復練習(hanpukurenshuu) latihan pengulangan kosakata baru. Strategi subtitution drill dilakukan oleh guru dalam memberikan siswa percakapan sederhana, kemudian siswa harus mengganti kosakata tertentu sesuai dengan pola kalimat yang diajarkan. Strategi ceramah digunakan dalam menjelaskan pola kalimat beserta conoh kalimat yang disertai terjemahan dalam bahasa Indonesia.

3. Faktor yang mendasaripenggunaan strategi yakni (1) karakteristik siswa yang memiliki tingkat kebosanan yang tinggi, (2) kemampuan yang dimiliki oleh siswa, (3) kondisi siswa di kelas dengan berbagai pertanyaan baik yang terkait maupun tidak terkait terhadap materi yang diajarkan.

4. Kendala-kendala yang dihadapi oleh guru bahasa Jepag di SD Mutiara Singaraja yakni (1) karakteristik siswa yang memiliki kemampuan berbeda dalam bahasa Jepang, (2) buku ajar.

\section{Saran}

Berdasarkan temuan dalam penelitian ini, berikut ini adalah beberapa saran yang dapat disampaikan.

1. Dalam proses pembelajaran, guru bahasa Jepang di SD Mutiara Singaraja sebaiknya menggunakan dan memikirkan kembali strategi permainan yang cocok mengingat memiliki karakteristik senang bermain.

2. Guru sebaiknya menyeimbangkan pelajaran bahasa dan budaya Jepang. Karena dalam tujuan pengadaan kegiatan ekstrakurikuler bahasa Jepang di SD Mutiara Singaraja diharapkan mampu memperoleh wawasan mengenai informasi dan budaya Jepang. 
Peneliti laindiharapkan mampu meneliti lebih dalam pembelajaran bahasa Jepang di tingkat SD secara menyeluruh contohnya memfokuskan juga pada penyajian materi pembelajaran dan bentuk penilaian dalam pembelajaran bahasa Jepang di SD Mutiara Singaraja.

\section{Daftar Pustaka}

Dharma, Surya. 2008. Strategi Pembelajaran Dan Pemilihannya. Jakarta: Departemen Pendidikan Nasional.

Dimyati dan Mudjiono. 2006. Belajar dan Pembelajaran. Jakarta: PT. Rineka Cipta.

Djamarah, Syaiful dan Zain, Aswan. (2006). Strategi Belajar Mengajar. Jakarta: Rineka Cipta.

Hamalik, Oemar. 2002. Perencanaan Pengajarn Berdasarkan Pendekatan Sistem. PT Bumi Angkasa: Jakarta.

Marsutayasa, D. M. A. 2016. Profil Strategi Pembelajaran Bahasa Jepang Berbasis Kurikulum 2013 di SMAN 4 Singaraja. Skripsi (tidak diterbitkan). Jurusan Pendidikan Bahasa Jepang, Universitas Pendidikan Ganesha Singaraja.

Padmadewi, Ni Nyoman. 2012. Strategi Pembelajaran Bahasa. Singaraja: Undiksha Press.

Roestiyah. 2008. Strategi Belajar Mengajar. Jakarta: Rineka Cipta.

Soewarno, dkk. 2016. "Kendala-Kendala Yang Dihadapi Guru Dalam Memanfaatkan Media Berbasis Komputer Di SD Negeri 10 BandaAceh". JURNAL PESONA DASAR, Volume. 2, Nomor.4, April 2016 ( hlm 28-39).

Sumantri, Mulyani dan Syaodih, Nana. 2006. Perkembangan PesertaDidik. Cetakan Keenam. Jakarta: Universitas Terbuka.

Sunhaji. 2008. "Strategi Pembelajaran:Konsep Dan Aplikasinya". INSANIA, Volume 13, Nomor 3, Edisi September-Desember 2008 (hlm. 474-492).

Suryosubroto. 2009. Proses Belajar Mengajar Di Sekolah. Jakarta: Rineka Cipta.

Tarigan, Guntur. 1984. Pengajaran Kedwibahasaan. Bandung: Angkasa.

The Japan Foundation Survey. 2015. Tersedia pada https://www.jpf.go.jp/e/project/japanese/survey/result/survey15.html(diakses tanggal 15 Desember 2017).

Yastini, L. J. A. 2015. Profil Pembelajaran Menulis Huruf Jepang di SMAN 4 Singaraja.. Skripsi (tidak diterbitkan). Jurusan Pendidikan Bahasa Jepang, Universitas Pendidikan Ganesha Singaraja. 